\title{
Epistemological Exclusion: The Case of the Master's Degree Programmes in Clinical Psychology in South Africa
}

\section{Lesiba Baloyi \\ ORCID iD: https://orcid.org/0000-0002-7564-2556}

\begin{abstract}
The demise of apartheid in 1994 in South Africa did not transform the history and practice of epistemological exclusion in the psychology curricula in general and the training programmes of the Master's degree in Clinical Psychology in particular. The continued exclusion of African people's ways of being, knowing and doing from psychology curricula and Clinical Psychology training programmes reflects the unequal knowledge representation in favour of those of the dominant Euro-American minority. This situation does not advance the development of a culture-sensitive and an inclusive pedagogy and practice in psychology. This paper argues for epistemological parity and representativity of indigenous African 'psychology' discourses and Western discourses on psychology in the psychology curricula in South African universities. The inclusion of indigenous cultural traditions, value systems and languages in the psychology curricula is both an ethical and intellectual imperative. This paper adopts a philosophical approach, and then presents three case scenarios reflecting challenges in psychotherapy, assessment and research to advance the argument for deconstructive and reconstructive challenges in the quest for epistemological parity and representation in the psychology curriculum.
\end{abstract}

Keywords: epistemology, clinical psychology, African psychology, transformation, decolonization 


\section{Ukusilela Kwezindlelalwazi: Udaba Lwezinhlelo Zokufunda Iziqu ZeMastazi Kwezokwelapha Ngeso Lempilo Kwezesifundongqondo ENingizimu Afrika}

\section{Lesiba Baloyi \\ ORCID iD: https://orcid.org/0000-0002-7564-2556}

\section{Iqoqa}

Ukuqedwa kobandlululo ngonyaka we-1994 eNingizimu Afrika akuzange kuguqule umlando nezenzo zokukhishwa kwamakharikhulamu ezindlelalwazi jikelele nakuzinhlelo zokuqeqesha iziqu zeMastazi, ikakhulukazi kwezokwelapha ngeso lempilo. Ukuqhubeka nokubekwa eceleni kwezindlela zabantu abangama-Afrika zobubona, ukwazi nokwenza amakharikhulamu esifundongqondo nakuzinhlelo zokuqeqesha zesifundongqondo sokwelapha ngeso lempilo kuveza ukungalingani kokwethulwa kolwazi okuvuna labo abaqonelayo kulabo abayingcosana abangama-Euro-American. Lesi simo asiqhubeli phambili ukuthuthukiswa kwesiko elinozwelo nendlelakufunda embandakanyayo nanezenzo kusifundongqondo. Leli phepha liqagulisana nenkulumo yezindlelalwazi nokumeleleka 'kwesifundongqondo' sabomdabu base-Afrika kumataniswa nenkulumo yaseNtshonalanga kumakharikhulamu esifundongqondo emanyuvesi omdabu eNingizimu Afrika. Ukumbandakanywa kwezinkambiso zesiko lwezomdabu, izihlelo ezingamagugu nolimi kukharikhulamu yesifundongqondo kuyikho kokubili okuyimpoqo enqubonhle nobuhlakani. Leli phepha lisebenzisa indlela yenjulabuchopho, bese lethula kokuthathu okuwumfanekiso oveza izinselelo zokwelapha ngokwengqondo, ukuhlola nangocwaningo okuqhubeza ukuqagulisana kwezinselelo zokudiliza nezokwakha kabusha ekuthungatheni ukumataniswa kwendlelakwenza nokwethulwa kwekharikhulamu yesifundongqondo.

Amagama asemqoka: izindlelalwazi, ukwelapha ngeso lempilo kwezesifundongqondo, isifundongqondo ngokwase-Afrika, uguquko, ukulwisana nokuqonelwa 


\title{
Ku tshikeleriwa ka mativelo ya xintu eka nongonoko wa tidyondzo ta mastasi ya vutshunguri bya miehleketo eAfrika Dzonga
}

\author{
Lesiba Baloyi \\ ORCID iD: https://orcid.org/0000-0002-7564-2556
}

\section{Xitshuriwa}

Ku hela ka mfumo wa xihlawuhlawu hi lembe ra 1994 eAfrika Dzonga a swi cincangi matimu na ntolovelo wo khirha eka nxaxameto wa tidyndzo ta ntivo mianakanyo hi ku angarhela na minongonoko yo dyondzisa hi rixaladza eka 'Master's Degree' ya Vutshunguri bya ntivo miehleketo. Ku yisiwa emahlweni ka ku khirhiwa ka tindlela ta ku hanya ta vanhu va Vantima, ku komba vutivi na maendlelo ya minongonoko yo dyondzisa yo huma eka tidyondzo ta ntivo miehleketo na Vutshunguri bya ntivo miehleketo swi kombisa vuyimeri bya vutivi byo ka byi ga ringani lebyi tsakelaka ntlawa lowuntsongo wa matimba wa 'Euro-American'. Xiyimo lexi a xi yisi emahlweni van'wana ma kulelo ya ndhavuko wo twisa ku vava na ntivo vudyondzisi wo katsakanya no titolovela eka ntivo miehleketo. Papila leri ri burisana hi ku ringana ka ntivo mianakanyo na ku yimela ku burisana ka mafundza ka ntivo miehleketo ya Vantima xidzi va Afrika na ku hambana ka ntivo miehleketo ya Valungu va le ndzhandzheni wa malwandle eka tidyondzo ta ntivo miehleketo etiyunivhesiti ta Africa Dzonga. Ku katsakanyiwa ka mahanyelo ya mindhavuko ya Vantima xidzi, nkoka wa maendlelo na tindzimi eka tidyondzo ta miehleketo hinkwaswo i mahanyelo ya ndzeriso wa miehleketo. Papila leri ri teka ndlela ya ntivovuhleketi, kutani ri tlhela ri kombisa matshamelo manharhu ya timhaka leti ti nga se humelelaka leti kombisaka ntlhontlho eka vutshunguri bya mavabyi ya nhloko, ku kambela no lavisisa ku yisa emahlweni mbhurisano wo onha ku endlela ku kuma swo karhi na ku lulamisa mintlhontlho eku lavisiseni ka ku ringana ka ntivo mianakanyo na vuyimeri eka kharikhulamu ya ntivo mianakanyo. 
Maritu-nkulu: tindlela ta $\mathrm{ku}$ tiva, vutshunguri bya miehleketo, ntivomiehleketo wa xintu, mapfhumba yo hluvukisa, ku herisiwa ka xikoloni xamiehleketo

\section{Epistemological Exclusion: The Case of the Master's Degree Programmes in Clinical Psychology in South Africa}

The demise of apartheid in 1994 did not transform the exclusivist education paradigm in general, and the professional psychology training pedagogy and content in particular, in South African universities. Despite the different views regarding the transformation ${ }^{1}$ agenda that has dominated the South African higher education landscape since the new democratic dispensation (Le Grange 2004; Mkhize \& Ndimande-Hlongwa 2014; Segalo \& Cakata 2017) the author's view is that psychology as a field of study, research and practice has not been sufficiently transformed to address the diverse, epistemological, methodological, cultural and linguistic challenges embodied in its multicultural landscape. The argument here is that curriculum redesign in

${ }^{1}$ The concept 'transformation' is used with reservations. First, it is unduly silent on the philosophical distinction between form and substance. The problem with this silence is that it permits only - and perhaps inadvertently attention to form, while leaving the substance intact. Given the same substance different forms from time to time is not, strictly speaking, a trans-formation; a going beyond the form. It is, instead, re-formation, potentially akin to the leitmotif of the super reformanda, that is, the 'always reforming'. The second point of reservation is the concept that stands in sharp contrast to 'transformation'. It is trans-substantiation, that is, going beyond original substance by infusing it with content that effectively changes its quality. Epistemologically, this substance may not be understood only in material terms. It may, metaphorically be understood as cultural ways of knowing and doing. From this perspective, a cross-fertilisation of cultural values is the pathway to the 'transformation of values' in a manner that yields qualitatively different values. Accordingly, my preference is for trans-substantiation. I therefore use transformation in this essay under protest. (See Marcuse H. 1964. One-Dimensional Man: Studies in the Ideology of Advanced Industrial Society. California: Marxist Internet Archive.) 


\section{Lesiba Baloyi}

psychology ought to respond to these challenges in order to be truly pluriversal. African indigenous ways of knowing and doing continue to be seen as mere beliefs and superstitions (Anselm \& John 2015; Dei 2011). This tendency of relegating indigenous belief systems to the level of mere myth and superstition is therefore challenged (Denzin, Lincoln \& Smith 2008; Owusu-Ansah \& Mji 2013). The author's argument is that the continuing exclusion of indigenous epistemologies, cultural practices, and experiences from the psychology curriculum is ethically unjustifiable as well as being pedagogically unsustainable (Freire 2003; Baloyi \& Ramose 2016).

Properly construed, an indigenous education system should reflect the local philosophies, methodologies, cultural experiences, and languages of the people amongst whom such an education system is embedded (Mkhize \& Ndimande-Hlongwa 2014; Mpofu 2002; Nwoye 2015a; Okere, Njoku \& Devisch 2005; Smith 2012). Similarly, psychology as a field of study, research, and healing practice will reflect African cultural heritage, and the understanding of psychology as a 'science' will have found its locality in the social context (Magid 2011; Smith 2012). This means that education systems, and by implycation, psychology, will become the true depositories and conduits of local cultural experiences and knowledge systems of peoples in differing contexts.

The historically skewed reality depicted above therefore necessitates the radical transformation of the conceptual frameworks and language policies within the education system (Dei 2012a; Dei 2012b; Mkhize \& NdimandeHlongwa 2014) in order to reflect the cultural experiences of the indigenous African majority. Currently, there is a glaring absence of indigenous epistemological frameworks, methodologies and languages in the training of research and professional psychologists in South African universities (Mkhize, Dumisa \& Chitindingu 2014; Pillay, Ahmed \& Bawa 2013). The epistemological exclusion experienced in psychology violates the Republic of South Africa Constitution of 1996, article 2, sections 30 and 31 (1) a and b, which provide for the assertion of language and cultural rights and practices. The aim of this paper is to demonstrate that the current epistemological injustice in psychology is ethically unsustainable and thus calls for rectification.

\section{The Current State of Psychology}

The psychology and clinical psychology training programmes, as they currently stand, are far from reflecting African thought and value systems. The 
thousands of books on psychology that are found in most African and South African libraries reflect foreign theories, knowledge systems, and treatment modalities. The content of psychology contained in most psychology literature is such that it advances epistemicide. Dei (2011) defines epistimicide and linguicide as a deliberate attempt to exterminate indigenous knowledge systems, cultures, and languages. This is because the African epistemological paradigm, cultural experiences, and traditions are seen as unscientific, mythical, or mere superstitions in academe (Baloyi \& Makobe-Rabothata 2014; Anselm \& John 2015). This claim is disputed because it is based on supremacist thinking, which positions Euro-Western ways of knowing as more valid and scientific than other ways of knowing. Psychology as we know it today within academic institutions is a branch of science emanating from the West (Mkhize 2004). If psychology is indeed representative, it should then reflect, as the mirror would, all realities irrespective of the origin, race and epistemological paradigm of the people concerned. For psychology to claim to be universal and objective, while denying other realities equal recognition and legitimacy, is contradictory to the very concepts of objectivity and universality.

Significantly, it is a previously colonised people's indigenous knowledge systems and traditions that are excluded from the education and psychology curriculum (Nwoye 2015a; and Nwoye 2018). This means that psychology in its current form represents a racialised field and practice, because of its willful exclusivity. It is of critical importance to investigate why it is that psychology, having an inquiry and treatment method that results in a 'therapeutic effect', continues to be blind to the fact that 'therapeutic effects' can be achieved through other forms of 'therapeutic methods' which are culturally and locally relevant, such as those of Africans. If we, for example, take a look at psychology textbooks like Becvar and Becvar (2009), Family Therapy: A systemic integration, $7^{\text {th }}$ edition, and Bernstein, Penner, ClarkeSteward and Roy (2006) titled Psychology, $7^{\text {th }}$ edition, there is little focus in these books on indigenous cultures and experiences. The exclusion of African ways of being, knowing, and doing from the dominant Western conceived psychology curricula through prescribed text books, articles and other sources is epistemologically and ethically problematic, because Western psychology cannot claim universal applicability in African contexts. The pedagogic foundation on which the current psychology curriculum is based is thus highly questionable. Below is the current structural design and state of clinical psychology training in South Africa. 


\section{The Current Structure of Clinical Psychology Training Programmes}

The Master's degree in Clinical Psychology is a Department of Higher Education and Training (DHET) directed professional qualification. Registered psychologists are expected to have clinical competencies, which enable them to work with people who present with problems of a clinical nature in varied contexts. The Masters in Clinical Psychology is one of several Masters' degree programmes in the discipline of psychology offered by South African universities. During the Clinical Psychology training period, and after qualifying as clinical psychologists, these professionals register in different categories and at different levels (for example, student, intern and clinical psychologist) with the Health Professions Council of South Africa (HPCSA) which is a statutory standard and ethics-generating and professional body. While the Professional Board of Psychology, which falls under the HPCSA, is responsible for the different categories of psychology, the focus of this paper will be limited to the Masters in Clinical Psychology training programmes.

South African universities that offer Masters Clinical Psychology training base their curricula on broad professional competency areas and standards determined by the Professional Board of Psychology. These core courses include Assessment and Diagnostics, Psychopathology, and Psychotherapy conceptualised from different Euro-American theoretical perspectives, (Kottler \& Swart 2004), Neuropsychology, Community Psychology, Research Methodology, and the DSM IV Classification Manual. The theoretical orientation, focus and content of Clinical Psychology training programmes varies from institution to institution (Pillay, Ahmed \& Bawa 2013). The responsibility of the Professional Board of Psychology is to regulate the professional competencies and ethical conduct of students and psychologists so as to ensure that clients are treated professionally and ethically by the practitioners serving them. African psychology and indigenous languages are glaringly absent from the core offerings mentioned above. This despite the HPCSA's call for professional training programmes to ensure that psychological services provided to clients and communities are culturally appropriate (Mkhize, Dumisa \& Chitindingu 2014).

Universities are responsible for the development and presentation of the course content, while hospitals and other institutions provide accredited sites for clinical training and practice. The Professional Board of Psychology 
verifies the competency of persons who qualify as clinical psychologists through regular visits to accredited clinical practice sites, and by examining these professionals through Board examinations, before they can be granted a licence to practise as independent practitioners. The already qualified and registered psychologists are periodically audited by the HPCSA to ensure compliance with the Continuing Professional Development requirement. These generic courses are premised on the colonial philosophical thought and value system refined through time. These are still presented to students and applied to local communities as if they have universal applicability (Baloyi \& Ramose 2016; Matoane 2012; Nobles 2006). The point to be emphasised here is that African epistemological conceptions of reality are different from the Western understanding of the world. Understanding, recognising and accepting this fact will assist universities and the Professional Board of Psychology to comprehend the African approach to knowledge and then restructure and redesign the Clinical Psychology curricula accordingly. This does not in any way suggest that the contribution made by Western psychology should be denied.

According to Mkhize, Dumisa and Chitindingu (2014:134), in its attempt to transform the profession of psychology, the HPCSA also 'Requires psychologists to ensure that culturally appropriate services are provided to clients'. It is however not clear what 'culturally appropriate services' entail and how the knowledge about these services and their applicability to local indigenous communities should be included in the curricula since little to no culturally appropriate material is provided. This exclusion will be discussed below.

\section{Epistemological Exclusion}

The epistemological injustice embodied in these professional Clinical Psychology training programmes involves the conspicuous absence of anything African. Although African trainees and students are in the majority, foreign theorisations and treatment modalities are emphasised in their training. This despite the fact that these trainees will after completion live among and work with indigenous African communities (Mpofu 2002). Moreover, African languages are yet to be used in the teaching of African epistemology with methodologies and treatment modalities appropriate to it. It is on this basis that the author argues that the Professional Board of Psychology ought to make 
African psychology and indigenous languages mandatory for psychology students and professional psychologists' certification to practice in South Africa (Pillay \& Kramers 2003). Cultural competency and language proficiency are human rights issues, which require urgent inclusion in professional training programmes such as Clinical Psychology training.

\section{Clinical Psychology Training and the Cultural Context}

Clinical Psychologists in South Africa work within diverse cultural contexts and these require cultural competence and understanding of indigenous languages and worldviews. Mkhize and Ndimande-Hlongwa (2014: 11) argue that:

In view of the fact that language is a major vehicle of communication and inter-subjective understanding, the transformation of the humanities and social sciences cannot be achieved without paying attention to language.

Consequently, it is important that clinical psychologists (in South Africa in particular and Africa in general) understand the epistemology, culture, experiences and languages of the indigenous communities, if they are to assist their clients effectively. It is inconceivable that clinical psychologists working with the black majority in South Africa can effectively assist clients without, for example, understanding the significance and role of the living-dead (ancestors); the performance of rituals; and ubuntu, its meaning and manifestations. Educational transformation and curriculum re-design in particular should include these fundaments. In this way, curriculum transformation will reflect the identity of African universities, and not universities in Africa as epitomised by the current Western conceived theories and treatment modalities in psychology.

The examples below illustrate why the inclusion of African epistemological paradigms, worldviews, and languages in the psychology curricula are necessary. These are not speculative examples. They are scenarios drawn from real discussions and teacher-student pedagogical experiences, and they extend to conversations on general experiences with clinical psychologists. These conversations occur outside the classroom context. 


\section{Case 1}

Tintswalo, a 35-year-old xiTsonga speaking man is an IT executive at a multinational company. He consulted a white psychologist for couples therapy due to marital problems. His wife apparently relied heavily on her grandmother and aunt for advice regarding her marital problems. According to Tintswalo, the problem was not that his wife consulted the grandmother and aunt, but rather that she was not listening to their advice. After exploring the issues and dynamics of the marriage with him, Tintswalo indicated to the psychologist that he would have to call their respective uncles, who negotiated his lobola, ${ }^{2}$ for a meeting to resolve their problems. He even suggested that these elders should maybe perform a ritual to appease their ancestors as a possible solution to their misunderstanding. Upon hearing the proposed intervention from his client the psychologist remarked: 'Tintswalo you are very educated and financially independent to be able to handle your problems. Why are you people so dependent on other people's views to make decisions? You need to think for yourself and your wife's future and stop asking your relatives to interfere in your affairs. Your ancestors are dead and have no influence on what is happening between you and your wife's marital problems.

In the above case, the psychologist completely misunderstood, misrepresented, and disrespected Tintswalo's worldview and cultural background. He did not seem to understand the role and influence of elders and ancestors in traditional African families and communities. He dismissed the substantive communal undergirding of Tintswalo's culture, and imposed his own cultural values upon the therapeutic process. The interdependence, coexistence, spiritual, and communal ways of conceiving and understanding people's problems and relatedness eluded the psychologist completely. He does not challenge the fundamental cultural assumptions underlying his provision of mental health services (Abe, Grills, Ghavami, Xiong, Davis \& Johnson 2018). Predictably, going forward the psychologist is likely to 'misdiagnose' the

${ }^{2}$ In African cultures, $u k u$-lobola can be seen as a social-cultural-spiritual symbol that has spiritual links (connecting and appeasing the ancestors) in uniting two families. The symbolic meaning of uku-lobola goes beyond the mere payment of money or cows. In practical terms, it constitutes the introduction of the groom and bride groom into each other's ancestral family network (see for example Khumalo 1997). 
problem, ineffectively conceptualise the issues facing his client, and is unlikely to avoid crafting an intervention that will be inadequate to his client's worldview and culture.

\section{The Imperative to Transform Clinical Psychology Training Programmes}

It is commendable that the Professional Board of Psychology and Psychological Society of South Africa have since the 1990s embarked on the process of transforming the field of psychology. In the author's observation and experience, what has been 'transformed' is the quantitative composition of the teaching staff to fit the Affirmative Action and Equity Legislative requirements. The content and meaning of what is being taught and its relevance and applicability to African communities has received very little attention. Granted, more black lecturers and learners are gradually being brought into the higher education system, and Clinical Psychology training programmes to address the legacy of policies that excluded the African majority from the educational landscape. However, the training, pedagogy, theories and methodologies which these lecturers teach remain rooted in EuroAmerican epistemology and value systems.

On this basis, the black lecturers, unless they are critical of the epistemological paradigms, then objectively become the mouthpiece and transmission belts of the Euro-American knowledge and value systems. The African epistemological paradigm is not yet recognised as a legitimate paradigm of 'psychology' (Wilson \& Williams 2013). Whenever African experiences, practices, and worldviews are used in textbooks and articles, it is usually done to justify the universal applicability and authenticity of these foreign theories, conventions, and interventions on indigenous communities. In trying to understand Africans, psychologists [in South Africa and Africa] continue to use conceptual categories and theories developed in the West (Grills 2002; Obasi 2002; Parham 2002). Researchers such as Kottler and Swart (2004) and Macleod (2004) have drawn attention to the calls for appropriate models and curriculum re-design to be consonant with South African and African needs in the field of psychology in general and professional psychology in particular. Despite these calls, there have been minor positive epistemological shifts within the psychology curriculum (Nwoye 2018) and little funded research in this area. Part of the reason for this 
is the continuing open or subtle resistance to the ethical imperative to realise epistemological equality in practice. A routine but no less standardised subtle resistance is the claim that it is necessary to preserve scientific standards. Often, this claim is silent in the face of raising the question about whose standards?

\section{Case 2}

Nandi, is a 22-year-old female honours student in one of the previously white universities. She was called by her family to her rural village in Limpopo Province to attend a family ritual. The family slaughtered a goat and she assisted her uncle to hang its skin on the fence to dry. On Monday in class a professor introduced the Rorschach Ink Block Test (projective test consisting of ten cards), and individually asked students to state what they were seeing on the cards. When it was Nandi's turn, she looked at Card 4 and exclaimed: 'Wow, Prof., this looks like a skin of a slaughtered goat'. Several students confirmed Nandi's observation. Shocked by her response, the professor stopped teaching and requested to see Nandi privately. He suggested to Nandi that she had to see a clinical psychologist as a matter of urgency, because she displays repressed suicidal ideation, gross aggressive tendencies, and claimed that she was a danger to herself and others.

The above case illustrates that the professor does not understand and/or is not interested in the meaning Nandi associated with the picture on the card. Nandi's worldview and the cultural experiences which are key to understanding her response are totally disregarded. The 'diagnosis' given to Nandi is grossly inaccurate, misrepresentative of her actual real experience and worldview, and can thus have far-reaching consequences on her wellbeing.

The cultural issues emanating from the case above indicate that Clinical Psychology training programmes whose curricula do not include African conceptions of reality are most likely to result in psychologists who 'mis-diagnose' and misconstrue' clients' problems in therapy. The result of this imposition of Euro-American epistemological paradigms is the cultural alienation and killing of indigenous people's ways of knowing and doing (Dei 2011). The exclusion of African perspectives, reality and existence from the psychology curriculum constitutes an epistemological injustice. The two cases will predictably evoke indignation on the part of those far-removed from the 
everyday life of indigenous Africans. They might even be construed as offensive. These possible reactions neither annul nor diminish the everyday reality of the indigenous Africans. They are best understood as an invitation to continue questioning the reality of epistemological exclusion in psychology and all other scientific disciplines. They are an invitation to become engaged in the struggle for epistemic justice.

\section{Higher Education and Indigenous 'Psychology'}

Consistent with Motha's (2009) argument that the recognition of indigenous law as law is a condition of any genuine approach to post-colonial justice, the recognition of indigenous or African-centered 'psychology' as authentic psychology should become the basis of a genuine post-colonial reconstruction and curriculum re-design. The definition and meaning of what African 'psychology' is to Africans should be based on African epistemology, ontology, culture, experience, and languages (Mkhize 2004). Nobles (2006) and Owusu-Ansah \& Mji (2013) argue that an understanding of a people's worldview, history and cultural context are extremely important, because it is via their explication and their intrinsic implications that one clarifies the relevance of the content and cultural context.

Dussel (1985) and Freire (2003) support this emancipatory dimension, which they see as 'liberation praxis', and argue that this has to be determined by the marginalised, oppressed, and dispossessed. It is a truism that the 'liberation praxis' in psychology required in South Africa cannot be considered inclusive and relevant psychology, unless it is defined by Africans themselves, based on African cultural experiences and knowledge systems that both broadly and intimately characterise South African society (Owusu-Ansah \& Mji 2013).

\section{Defining African Psychology}

According to Grills (2006: 172), African-centered psychology is a 'psychology which is concerned with African psychological experiences from an African perspective which reflects an African orientation to the meaning of life, the world and relationships with others and oneself'. Nwoye (2015a: 104) defines African psychology as the 'systematic and informed study of the complexities of human mental life, culture and experiences in the pre-and post-colonial 
African world'. These definitions clearly indicate that, in understanding African experiences, African worldviews and traditions should be the reference point (Anselm \& John 2015). These positions are consistent with other discussions that argue that research and praxis in psychology should be grounded in culture and context. The Ecological Validity Model (Bernal, Bonilla \& Bellido 1995), for instance, identifies eight dimensions (e.g. language, persons, metaphors, content, concepts, goals, methods, and context) that should guide the development of culturally anchored treatment modalities that are relevant for different ethno-cultural groups.

\section{Indigenous Epistemologies and Methodologies in Psychology}

In all the Master's clinical training programmes at South African universities, African students are expected to master a foreign psychology that is conceptualised in terms of Western experiences and cultures. The relevance and authenticity of the epistemology they work from, therefore, becomes highly questionable when applied to traditional African communities for at least two reasons. First, the few number of African lecturers teaching and students selected in Clinical Psychology training programmes, especially in the previously white universities, and the dominance of a foreign epistemology and course content reflect unjust racist and epistemological exclusion (Dei 2011). This is unethical conduct in psychology in general, and, it must be underscored, in the training of clinical psychologists, in particular, especially if the disciplines wishes to be culturally inclusive.

The case below illustrates the inconsistencies that occur when foreign theorisations and methodologies are applied to the experiences of indigenous communities.

\section{Case 3}

Musa is a 26-year-old student in a Master's in Clinical Psychology training programme. He is a member of the local djembe drumming group in a township. Musa is interested in investigating the psychological healing benefits of djembe drumming on this group of drummers. He, however, does not know what methodology and research design he should use in his investigation. He approaches a black lecturer who is Western-trained to supervise him. The lecturer suggests to him to observe the drummers, video-tape and interview 
them after the performance, and then transcribe their narratives following a set schedule in their prescribed research methodology book. A conflict ensues between them, because the lecturer insists on traditional qualitative methodology with prescribed steps. Having read several articles and books on indigenous research methodologies, Musa decides to explore the possibility of adopting performance as his method, reasoning that it is consistent with his African epistemological paradigm. Their differences in approach are not resolved, and Musa submits his research protocol to the University Research Committee. His protocol is failed on the basis that his research methodology does not comply with 'established' and 'prescribed' scientific universally acceptable methodologies.

The above case indicates the tension and differences that exist between EuroAmerican and indigenous research methodologies (Smith 2012). In most cases, the methodology that is conceived from the grand narrative epistemological paradigm is adopted, irrespective of whether it addresses the research question or not.

There is no question about the authenticity and intellectual viability of African indigenous research methodologies (Okere \& Nkwocha 2003) and languages in facilitating therapy and understanding people's experiences, ways of knowing and doing (Mkhize, Dumisa \& Chitindingu 2014). The call for the recognition and inclusion of the linguistic, theoretical, and epistemological perspectives of the indigenous experiences and cultures in the curriculum (Kincheloe \& Steinberg 2008) is likely to create what Motha (2009) calls 'the naming of a historical wound' that many psychology training programme directors and institutions of higher education in South Africa are afraid to undertake.

\section{Epistemological Racism in Clinical Psychology Programmes}

Western psychology is a reflection of a particular epistemological paradigm and worldview. It cannot, therefore, be divorced from the political and historical reality, whose open aim was to eradicate indigenous epistemologies. Against this background, curriculum and epistemological racism is not a random phenomenon, and it is certainly not only a South African problem. It is still prevalent in academic contexts in countries such as India, Sri Lanka, Australia, New Zealand, Canada (Motha 2009) and the United States of 
America, to name merely a short list. It represents institutionally structured racism that people of colour are exposed to in the form of everyday racist discourse. It has become the subject of significant discussion within movements such as the Forum of African Psychology in South Africa, and the Association of Black Psychologists in the United States to promote an 'African indigenous psychology' (Kim, Yang \& Hwang 2006), which challenges the claim of universal validity touted in Western psychology (Chakkarath 2012).

The argument in this paper is that the continuation of epistemological exclusion and racism in Clinical Psychology training contexts is unjustified, unambiguously harmful, and perpetuates oppression. Lyons, Bike, Johnson and Bethea (2012) argue that research in traditional Western psychology deemed people of African descent to be intellectually deficient and unable to even grasp psychology. The racism and oppression contained in this view were disregarded whenever the Westerner conducted inquiries into the psychology of people of African descent. It is therefore only fit and proper that psychology take up the challenge of the deracialisation of Clinical Psychology training in general, and particularly in a deeply polarised South African society.

Literature on the 'fees must fall' phenomenon continues to proliferate. It is varied. Some authors focus on the relationship between poverty and the ethical imperative to abolish fees altogether, or to make special concessions to the poor. Others focus on the question whether or not 'fees must fall' includes 'the destruction of property'. Yet another group of commentators and writes prefer to focus upon the affordability of a fees-free higher education. Few, however, have directly and expressly devoted special attention to the psychology underlying the fees must fall movement. The core question of psychology with regard to the 'fees must fall' movement is, I argue: what are the historical and social factors conducive and contributory to a psychological mind-set espousing 'fees must fall'? Since this espousal is situated in a racialhistorical-social context, it is pertinent to identify the social background and position of both the proponents as well as the opponents of the 'fees must fall' movement. The thesis of relative deprivation is relevant to the identification. Instead of an elaborate explanation of this well-known thesis, I consider if best to employ the metaphor of 'psychology' from the standpoint of an 'empty stomach', and psychology from the position of a 'full stomach'. The former is the identification of the structurally and systemically impoverished indigenous peoples conquered in the unjust wars of colonisation. The latter designates the colonial conqueror and its posterity. 


\section{Reflections}

From the exposition above, the need for an African conception of 'psychology' based on African philosophy, methodologies, traditions and languages is critical. Educators and trainers should, however, sensitively consider how the development, design, and implementation of such a Clinical Psychology transformative curriculum agenda should be carried out to avoid the possibility of conversely marginalising the voices and epistemologies of white minority groups. In this regard, the need for legitimate dialogical and pluriversal conversations in which there is willingness to listen to others' expressions and points of view becomes very significant, no matter how 'ill-informed' (Waghid 2004). To this effect, an inclusive-on-equal-basis epistemological conversational space is both necessary and imperative for psychology to become representative, relevant and legitimate in South Africa. In the more than two decades of training, clinical psychologists, clinical case supervision, and serving as an external examiner (for dissertations and psychotherapy examinations) for several South African universities, the author has observed how students, interns and clinical psychologists/lecturers struggle to conceptualise patients' problems from an African cultural point of view. The result of this has been the imposition of irrelevant Western conceived treatment modalities on patients or adopting research designs, which are alien and at odds with local experiences. It is against this background that the author has developed and taught an African psychology course for Masters Clinical Psychology training at two South African universities.

The marginalisation of African epistemology highlighted by its exclusion from the mainstream psychology curricula in South Africa must be corrected. The rectification may be in the form of academic collaboration aimed at making the study of African psychology and languages a matter of course in South African universities. Dei (2012a: 113) refers to these collaborations as 'the recognition of interdependence of scholarship, politics and activism'. It is my submission that this transformation and deracialisation process cannot be adequately conceived unless the dominant paradigm of psychology is deconstructed and reconstructed. The growing body of literature calling for the inclusion of indigenous knowledge systems in psychology curricula is a positive step in the right direction (Nwoye 2018; Denzin, Lincoln \& Smith 2008; Chakkarath 2005). However, true conceptual decolonisation programmes (Kazeem 2012) and epistemological inclusion will only begin to 
be achieved when the curriculum of Psychology reflects the culture and experiences of indigenous Africans in their own space.

\section{Conclusion}

Credit must be given to the Professional Board of Psychology's recognition of the need for cultural competency and sensitivity on the part of professional psychologists working with indigenous communities in South Africa. There is, however, greater need for the Professional Board of Psychology to seriously consider prescribing an African Psychology module/course and a regionally relevant African language (depending on the region where the university is located) as pre-requisite in Psychology in general, and South African universities (Mkhize \& Ndimande-Hlongwa 2014) and the Masters in Clinical Psychology training programmes in particular.

The view taken in this paper is that African indigenous worldviews, methodologies, therapeutic/healing modalities, cultural experiences, traditions and languages continue to be marginalised in psychology and the Clinical Psychology curriculum of almost all South African universities. The low intake levels of African students in previously white universities continues to maintain racial imbalances in their Masters Clinical Psychology training programmes. The process of transforming and deracialising the current clinical training discourse should start with the inclusion of local cultural experiences and African languages in the psychology curricula, premised on the philosophy of ubuntu, as well as the eradication of the dominance of the Western epistemological paradigm. There can be no social justice without epistemic justice in Africa and the world, because the very act of study is in itself a matter of ethics (Ramose 2016).

\section{References}

Abe, J., C. Grills, N. Ghavami, G. Xiong, C. Davis \& C. Johnson 2018. Making the Invisible Visible: Identifying and Articulating Culture in Practicebased Evidence. American Journal of Community Psychology 62, 1-2: 1 14.

https://doi.org/10.1002/ajcp.12266

PMid:30106473 
Anselm, J. \& T. John 2015. African Epistemological Approach to Epistemic Certitude and Scepticism. Research on Humanities and Social Sciences 5: $54-61$.

Asante, M.K. 1991. The Afrocentric Idea in Education. Journal of Negro Education 60: 170 - 180.

https://doi.org/10.2307/2295608

Baloyi, L.J. \& M. Makobe-Rabothata 2014. The African Conception of Death: A Cultural Implication. In Jackson, L., D. Meiring, F.J.R. van der Vijver \& E. Idemudia (eds.): Towards Sustainable Development through Nurturing (or Appreciating) Diversity. Available:

http://iaccp.org/sites/default/files/stellenbosch_pdf/Baloyi.pdf

Baloyi, L.J. \& M.B. Ramose 2016. Psychology and Psychotherapy Redefined from the Viewpoint of the African Experience. Alternation Special Edition 18: 12 - 35 .

http://alternation.ukzn.ac.za/Files/docs/23\%20SpEd18/01\%20Baloyi\%2 0F.pdf

Battiste, M. 2008. Research Ethics for Protecting Indigenous Knowledge and Heritage. In Denzin, N.K., Y.S. Lincoln \& L.T. Smith (eds.): Handbook of Critical and Indigenous Methodologies. California: SAGE Publications.

Bernal, G., J. Bonilla \& C. Bellido 1995. Ecological Validity and Cultural Sensitivity for Outcome Research: Issues for the Cultural Adaptation and Development of Psychosocial Treatments with Hispanics. Journal of Abnormal Child Psychology 23: 67 - 82.

https://doi.org/10.1007/BF01447045

PMid:7759675

Chakkarath, P. 2005. What can Western Psychology Learn from Indigenous Psychologies? Lessons from Hindu Psychology. In Friedlmeier, W., P. Chakkarath \& B. Schwarz (eds.): Culture and Human Development: The Importance of Cross-cultural Research to the Social Sciences. New York: Psychology Press.

Chakkarath, P. 2012. The Role of Indigenous Psychology in the Building of Basic Cultural Psychology. In Valsiner, J. (ed.): The Oxford Handbook of Culture and Psychology. Oxford: Oxford University Press. https://doi.org/10.1093/oxfordhb/9780195396430.013.0005

Dei, G.J.S. 2011. Indigenous Knowledges in the [African] Academy: Resisting a Binary and an Epistemological Divide. Paper presented in November at 
Graduate seminar, College of Education, University of South Africa: Pretoria.

Dei, G.J.S. 2012a. Indigenous Anti-colonial Knowledge as 'Heritage Knowledge' for Promoting Black/ African Education in Diasporic Contexts. Decolonization: Indigeneity, Education \& Society 1:102 - 119. Dei, G.J.S. 2012b. Reclaiming our Africanness in Diasporized Contexts: The Challenge of Asserting a Critical Personality. The Journal of Pan African Studies 4: 42-57.

Denzin, N.K., Y.S. Lincoln \& L.T. Smith (eds.) 2008. Handbook of Critical Indigenous Methodologies. California: SAGE Publications.

https://doi.org/10.4135/9781483385686

PMid:19019088

Dussel, E. 1985. Philosophy of Liberation. New York: Orbis Books. Freire, P. 2003. Pedagogy of the Oppressed. New York: Continuum. Grills, C. 2002. African-centered Psychology: Basic Principles. In Parham, PA (ed.): Counseling Persons of African Descent: Raising the Bar of Practitioner Competence. London: Sage.

Kazeem, F.A. 2012. H. Odera and the Question of Methodology in African Philosophy: A Critique. Special Issue: Odera Oruka Seventeen Years on:

Thought and Practice. A Journal of the Philosophical Association of Kenya (PAK) New Series 4: 185 - 204.

Khumalo, Z.L.M. 1997. A Critical Analysis of Traditional Marriage.

Unpublished Doctoral Dissertation. University of Natal, Durban.

Kim, U., K.S. Yang \& K.K. Hwang 2006. Indigenous and Cultural Psychology: Understanding People in Context. New York: Springer.

https://doi.org/10.1007/0-387-28662-4

Kincheloe, J.L. 2003. Critical Ontology: Visions of Selfhood and Curriculum. Journal of Curriculum Theorizing 19: 47 - 64.

Kincheloe, J.L. \& S.R. Steinberg 2008. Indigenous Knowledges in Education: Complexities, Dangers and Profound Benefits. In Denzin, N.L., Y.S. Lincoln \& L.T. Smith (eds.): Handbook of Critical Indigenous Methodologies. California: SAGE Publications.

Kottler, A. \& S. Swartz 2004. Rites of Passage: Identity and the Training of Clinical Psychologists in the Current South African Context. South African Journal of Psychology 34, 1: 55 - 71.

https://doi.org/10.1177/008124630403400103

Le Grange, L. 2004. (South) African(a) Philosophy of Education: A Reply to 
Higgs and Parker. Journal of Education 34: 144 - 153.

Lyons, H.Z., D.H. Bike, A. Johnson \& A. Bethea 2012. Culturally Competent Qualitative Research with People of African Descent. The Journal of Black Psychology 38: 153 - 171.

https://doi.org/10.1177/0095798411414019

Macleod, C. 2004. South African Psychology and 'Relevance': Continuing Challenges. South African Journal of Psychology 34: 613 - 629.

https://doi.org/10.1177/008124630403400407

Magid, A. 2011. African Indigenous Knowledge Systems: Challenges and Opportunities. Africa Insight 40: 136 - 148.

https://doi.org/10.4314/ai.v40i4.65935

Marcuse, H. 1964. One-Dimensional Man: Studies in the Ideology of Advanced Industrial Society. California: Marxist Internet Archive.

Matoane, M. 2012. Locating Context in Counselling: The Development of Indigenous Psychology in South Africa. Theory, Culture \& Society 27: $285-305$.

Mkhize, N. 2004. Psychology: An African Perspective. In Hook, D., N. Mkhize, P. Kiguwa \& A. Collins (eds.): Critical Psychology. Cape Town: UCT Press.

Mkhize, N. \& N. Ndimande-Hlongwa 2014. African Languages, Indigenous Knowledge Systems (IKS), and the Transformation of the Humanities and Social Sciences in Higher Education. Alternation 21,2: 10 - 37.

http://alternation.ukzn.ac.za/Files/docs/21.2/02\%20Mkh.pdf

Mkhize, N., N. Dumisa \& E. Chitindingu 2014. Democratising Access and Success: IsiZulu Terminology Development and Bilingual Instruction in Psychology at the University of KwaZulu-Natal. Alternation 13: 128 154.

http://alternation.ukzn.ac.za/Files/docs/21\%20SpEd13/07\%20Mkhize\%2 OF.pdf

Motha, S. 2009. Archiving Colonial Sovereignty: From Ubuntu to a Jurisprudence of Sacrifice. SAPR/PL 24: 299 - 300.

Mpofu, E. 2002. Psychology in Sub-saharan Africa: Challenges, Prospects and Promises. International Journal of Psychology 37: 179 - 186.

https://doi.org/10.1080/00207590244000061

Nobles, W.W. 2006. Seeking the Sakhu: Foundations for an African Psychology. Chicago: Third World Press.

Nwoye, A. 2015a. What is African Psychology the Psychology Of? Theory \& 
Psychology 25: 96 - 116.

https://doi.org/10.1177/0959354314565116

Nwoye, A. 2015b. African Psychology and the Afrocentric Paradigm to

Clinical Diagnosis and Treatment. South African Journal of Psychology 45: $305-317$.

https://doi.org/10.1177/0081246315570960

Nwoye, A. 2018. African Psychology and the Emergence of the Madiban Tradition. Theory \& Psychology 28, 1: 38 - 64.

https://doi.org/10.1177/0959354317742204

Obasi, E.M. 2002. Reconceptualising the Notion of Self from the African

Deep Structure. In Parham, T.A. (ed.): Counselling Persons of African

Descent: Raising the Bar of Practitioner Competence. London: Sage.

Okere, T.I. \& L. Nkwocha (eds.) 2003. Harvesting and Sharing Indigenous Knowledge in Africa. International Symposium. Owerri, Nigeria.

Assumpta Press.

https://doi.org/10.4314/ad.v30i3.22226

Okere, T.I., C.A. Njoku \& R. Devisch 2005. All Knowledge is First of All Local Knowledge: An Introduction. African Development 30,3: 1 - 19.

Oluwole, S.B. 1992. Witchcraft, Reincarnation and the God-head. Lagos: Excel Publishers.

Osuwu-Ansah, F.E. \& G. Mji 2013. African Indigenous Knowledge and Research. African Journal of Disability 2,1.

Available at:

https://ajod.org/index.php/ajod/article/view/30/56

https://doi.org/10.4102/ajod.v2i1.30

PMid:28729984 PMCid:PMC5442578

Parham, T.A. (ed.) 2002. Counselling African Americans: The Current State of Affairs. In Parham, T.A. (ed.): Counselling Persons of African

Descent: Raising the Bar of Practitioner Competence. London: Sage.

Park, E. 2007. Global Justice and Psychology. European Representations of African Poverty. Journal of Social Distress and the Homeless 16: 134 171.

https://doi.org/10.1179/sdh.2007.16.3.135

Pillay, A.L. \& A.L. Kramer 2003. South African Clinical Psychology, Employment (in) Equity and the Brain Drain. South African Journal of Psychology 33: 52 - 60.

https://doi.org/10.1177/008124630303300107 
Pillay, A.L., R. Ahmed \& U. Bawa 2013. Clinical Psychology Training in South Africa: A Call to Action. South African Journal of Psychology 43: $46-58$.

https://doi.org/10.1177/0081246312474411

Ramose, M.B. 2016. Interview with Professor Mogobe Ramose by Azuku Nzegwu. Journal of African Philosophy 14: 93 - 100.

Segalo, P. \& Z. Cakata 2017. A Psychology in our Own Language: Redefining Psychology in an African Context. Psychology in Society 52: 29 - 41.

Smith, L.T. 2012. Decolonizing Methodologies: Research and Indigenous People. $2^{\text {nd }}$ Edition. London \& New York: Zed Books.

Stevens, G., V. Franci \& T. Swart (eds.) 2006. A Race Against Time: Psychology and Challenges to Deracialisation in South Africa. Pretoria: University of South Africa.

Waghid, Y. 2004. Revisiting the African - Africana Philosophy of Education Debate: Implications for University Teaching. Journal of Education 34: $127-142$.

https://doi.org/10.1080/18146620408566268

Wilson, D. \& V. Williams 2013. Ubuntu: Development and Framework of a Specific Model of Positive Mental Health. Psychology Journal 10,2: 80 100.

Lesiba Baloyi Professor

Department of Clinical Psychology Sefako Makgatho Health Sciences University

Ga-Rankuwa lesiba.baloyi@smu.ac.za 